\title{
CAPITAL MARKET COINTEGRATION AND DECISION BUY-SELL STOCK
}

\author{
ELIZABETH LUCKY MARETHA SITINJAK* \\ YUSNI WARASTUTI* \\ FEB Unika Soegijapranata
}

\begin{abstract}
The problem in this study is whether the Indonesian Capital Market is coupled with the ASEAN Capital Market and East Asia Capital Market. And the interest rate of the US Federal Reserve (Fed Rate) and Central Bank of Indonesia's Interest Rates (BI Rate) against the decision of domestic investors and foreign sellingbuying of shares. The research model using EViews-9 for stationary testing (ADFTest), cointegration (Johansen-Test), and t-test and f-test automatically calculated by EViews-9. The study found their cointegration between Capital Markets in ASEAN (JCI, STI, KLSE, SET, PSE), cointegration in Capital Markets in EAST ASIA (NIKKEI, HSI, KOSPI, SHCOMP, TWSE), and cointegration Interest Rates (The Federal Fund Rate, Bank Indonesia Rate). The results of this study also showed that domestic investors in the Central Bank of Indonesia (BI Rate) are deciding to buy shares with the movement. Meanwhile, local investors in the decision to sell stocks saw the index movement of the KLSE and STI index (ASEAN Capital Markets), as well as the TWSE index (East ASIA Capital Market). Foreign Investors buy stocks to decide on the movement of the US Federal Reserve (the Fed) and the Bank Indonesia interest rate (BI Rate).
\end{abstract}

Keyword: Cointegration, Buy-Sell, ASEAN, East Asia.

Intisari: Masalah dalam penelitian ini adalah apakah Pasar Modal Indonesia digabungkan dengan Pasar Modal ASEAN dan Pasar Modal Asia Timur. Dan suku bunga Federal Reserve AS (Fed Rate) dan Suku Bunga Bank Indonesia (BI Rate) terhadap keputusan investor domestik dan penjualan-beli saham asing. Model penelitian menggunakan EViews-9 untuk pengujian stasioner (ADF-Test), kointegrasi (Johansen-Test), dan t-test dan f-test secara otomatis dihitung oleh EViews-9. Studi ini menemukan kointegrasi mereka antara Pasar Modal di ASEAN (JCI, STI, KLSE, SET, PSE), kointegrasi di Pasar Modal di ASIA TIMUR (NIKKEI, HSI, KOSPI, SHCOMP, TWSE), dan Suku Bunga kointegrasi (Suku Bunga Federal Rate), Suku Bunga Bank Indonesia). Hasil penelitian ini juga menunjukkan bahwa investor domestik di Bank Sentral Indonesia (BI Rate) memutuskan untuk membeli saham dengan pergerakan tersebut. Sementara itu, investor lokal dalam keputusan untuk menjual saham melihat pergerakan indeks KLSE dan indeks STI (Pasar Modal ASEAN), serta indeks TWSE (Pasar Modal ASIA Timur). Investor asing membeli

* Corresponding author: lucky@unika.ac.id,yusni@unika.ac.id 
saham untuk memutuskan pergerakan Federal Reserve AS (The Fed) dan suku bunga Bank Indonesia (BI Rate).

Kata Kunci: Kointegrasi, Jual-Beli, ASEAN, Asia Timur.

\section{Introduction}

The 2015 ASEAN Economic Community Blueprint (AEC Blueprint) was approved by ASEAN country leaders (Indonesia, Singapore, Malaysia, Thailand, Philippines, Vietnam, Myanmar, Laos and Brunei Darussalam) in November 2007. AEC Blueprint 2015 has a single market goal and production based on the free flow of goods, services, investments, capital, and skilled workers. Other purposes are to increase competitiveness, sound economic development, and global economic integrity.

The need for regional capital market integration is increasingly needed to grow and strengthen ASEAN's resilience. Individual ASEAN capital markets are small compared to non-ASEAN capital markets, with a limited range of products and services, relatively illiquid, with high transaction costs and large equity premiums because trading volumes have different scales. The ASEAN market needs to collaborate and achieve parity with developed markets so that ASEAN investors and issuers look to ASEAN as the preferred market (ASEAN Association, 2008).

The integration of the ASEAN capital market will enhance the role of the capital market in the economic development of ASEAN countries. The importance of the part of the capital market is according to Liaw (2005) because the capital market is a longterm source of funding for the corporation and for obtaining profits for investors.

2015 is the year the ASEAN capital market integrates if it is following the ASEAN Economic Community Blueprint. AEC Blueprint 2015 said it would develop capital market integration through its account transactions or conduct transactions with customer accounts. Besides that, the Indonesian Capital Market also participates in issuing various types of securities, with different asset management, as well as the completion of clearing services for financial assets. Capital market integration will allow for greater cross-border access to investors and issuers and help expand the 
investor base and various products, thereby strengthening the domestic capital market and providing liquidity, scale, capacity and ultimately placing ASEAN in a position to integrate with the global market (ASEAN Association, 2008).

The 2015 Bloomberg data showed that the Indonesia Stock Exchange market capitalization was in the eighth place of the Asia-Pacific Exchange Capital Market. In figure 1, there were three significant market capitalization, namely the Tokyo Stock Exchange (TSE $=4504$ issuers), Hong Kong Exchange (HKEX = 3411 issuers), Shanghai Stock Exchange (SSE $=3249$ issuers). These three countries are not included in the ASEAN Community, so this study chose the third index of the stock exchange to be an independent variable that affects the movement of the Indonesian Capital Market. Also, this stock exchange index is an index that is often used by investors in investing in the futures market.

The motivation of researchers here is to emphasize the desire of the Indonesian Capital Market to integrate with the capital markets of ASEAN and surrounding countries with the largest market capitalization. The Indonesian Capital Market currently has 577 issuers (www.idx.co.id , May 2018). The Indonesian Capital Market is still 20.66 percent from the Tokyo Stock Exchange, but the Indonesian Capital Market is still above Bursa Malaysia (BM $=504$ issuers), Thailand (SET $=464$ issuers), and the Philippines (PSE $=262$ issuers). In addition to the index of each ASEAN exchange (SGX, BM, SET, PSE) and five ASIA countries (Nikkei, HSI, KOSPI, SHCOMP, TWSE) used, this study also uses Bank Indonesia interest rates (BI Rate) and interest rates issued by the American central bank (Federal Fed Rate) as one of the independent variables tested on the Indonesian Capital Market. The combined income of the ASEAN Capital Market, if combined, will get a gross domestic income of USD 1.8 trillion with a total population of 538 million people or will rank in the eighth largest market in the world (Rahman, 2011).

The ASEAN Capital Market aims to reduce the volatility of the capital market volatility that is too high and can develop the domestic capital market and maintain its liquidity and increase its competitiveness. The interest rate issued by the Central Bank of the United States (Fed Rate) is predicted to affect the entire movement of the stock 
market index in the world scene. However, this study also includes the Bank Indonesia interest rate (BI Rate) as the interest rate that applies to the Indonesia economy. The BI Rate can influence the investment direction of an investor who sees macroeconomic factors as an analytical tool for trading stocks.

In figure 1, it shows that in the past three years, foreign investors have bought and sold transactions not exceeding domestic investors. This shows, transactions buying local investors, are still in line with the transactions bought by foreign investors. However, the selling transaction shows that the behavior of domestic investors is still dependent on selling by looking at foreign investors' reaction. Panic selling could be seen at the European Union British Exit (Brexit) on June 24, 2016, and British Prime Minister David Cameron has resigned since the final calculation of 52 percent supports leaving the European Union, and 48 percent said that he continues to join the European Union. The researcher suspects that investor behavior in Indonesia has a super-fast response to this information, so that panic selling occurs on that day, followed by herding behavior (buying and selling without understanding more in-depth information). However, after realizing the incident, because domestic investors are now bigger than foreign investors (60 percent of domestic investors, 40 percent of foreign investors), recovery is quick (down 2 percent to rise 2 percent again on the 3rd day since the Brexit incident).

The decision to buy and sell shares by domestic investors and foreign investors depends on the behavior of investors who tend to be irrational decisions rather than rational decisions. Sitinjak (2013) said irrational decisions are decisions that psychologically have positive emotions. The theory of disposition effect by Kahneman \& Twersky $(1979,2002)$ says that getting more loss, irrational investors are increasingly holding it back to sell, but on the contrary, once they get gain, the decision to sell is getting faster. This result is supported by the Sitinjak (2013) study. Besides that, the results of the survey by Sitinjak et al. (2014) said that there is accounting information that is relevant for shareholders to buy and hold long enough is Earning per Share (EPS). This affects the decision to buy and hold shares by domestic investors, which have been increasing over the years. 
Research on capital market integration along with the reaction of the decision to sell and buy shares is still minimal. Sari (2014) said that the American capital market, Singapore, Japan, was integrated with the Indonesian capital market. Besides, foreign portfolios affect the integration of the Indonesian Capital Market. This study emphasizes the testing of the effect of the integration of ASEAN Capital Market (JKSE, SGX, KLSE, SET, PSE), Capital Markets EAST ASIA (NIKKEI, HSI, KOSPI, SHCOMP, TWSE), and the interest rate the US Federal Reserve (Fed Rate) and the Indonesian Central Bank's Interest Rate (BI Rate) against buying decisions selling shares by domestic and foreign investors in the Indonesian Capital Market. This integration process to find out whether a capital market only affects other capital markets, or other capital markets only influence a capital market, or other capital markets in one region also influence a capital market other than influence.

Based on the background of the phenomenon and the results of previous studies, this study will look at the effect of ASEAN Capital Market integration (JKSE, SGX, KLSE, SET, PSE), East Asia Capital Markets (NIKKEI, HSI, KOSPI, SHCOMP, TWSE) and Bank Interest Rates The United States Central (Federal Fund Rate) and the Indonesian Central Bank's Interest Rate (BI Rate) against the decision to buy-sell shares by domestic and foreign investors in the Indonesian Capital Market. The purpose of this study is to investigate the effect of the integration of ASEAN Capital Market, Capital Markets EAST ASIA, and the interest rate the US Federal Reserve (Fed Rate) and Interest Rates Central Bank of Indonesia (BI) to the decision to sell-buy shares by domestic investors and foreign.

\section{THEORY FRAMEWORK AND HYPOTHESIS DEVELOPMENT}

\subsection{Theoretical Basis}

\subsection{ASEAN Capital Market Integration}

On the web, www.aseanexchanges.org said every ASEAN capital market recommends the best 30 stocks based on market capitalization and liquidity so that from all ASEAN countries there will be 210 best shares. Investors will see 
developments from two directions, both from domestic sales and integration sales with ASEAN countries. The Indonesian Capital Market has prepared IDX-30, where shares in it are to be able to compete with stocks in the ASEAN Capital Market and East ASIA Capital Market.

Rahman (2011) said that the Capital Market collaboration in the ASEAN Exchanges region also provides an opportunity to invest in ASEAN countries and has links with ASEAN countries (ASEANConnect). The ASEAN capital market offers a forum for promoting the ASEAN capital market to investors as well as potential domestic and foreign investors. An integrated capital market is a manifestation of the blueprint of the ASEAN Community. 2015 to 2020 are key to the movement of goods, services, investment and educated labor (national and international certified). Activities carried out by the ASEAN Community holds a road show to investment managers to promote ASEAN capital market products.

Meanwhile, ASEAN Connect is a new name from what was previously called the ASEAN Exchange Linkage, namely the integration of ASEAN exchanges. The initiator of the ASEAN Exchange Linkage is the Malaysia, Thailand and Singapore Exchange. The three initiators joined the Philippine Exchange, but the Vietnam Stock Exchange and the Indonesian Stock Exchange are still considering the right time to start participating. This is because the readiness of the Indonesia Stock Exchange (IDX) on the regulation of inter-country transactions is not yet mature so that the Indonesian Capital Market is planned to carry out integration in 2016 (www.ojk.go.id).

ASEAN Exchange is expected to help ASEAN to start building the financial markets are integrated in whose capital or funds can move freely in the region, a publisher of financial products (issuers) can seek funds elsewhere, while investors are also free to invest and transact anywhere in the capital market ASEAN is a competitive fee from one access (single access point).

The potential of the capital market of the six ASEAN countries is quite significant, namely a combination of gross domestic income reaching USD 1.8 trillion with a total population reaching 538 million people or occupying the eighth largest 
market in the world (the eighth largest market in terms of GDP). This ASEAN collaboration can create superior products and harmonize regulations; in the future, it is expected that this region can become one of the world-class assets and increase investment activities in the ASEAN region.

\section{1. 2. Interest rate}

Bank interest rates issued by a country is one of the factors that influence investors in investing in the capital market. Keynes's theory says the interest rate is determined by preference and supply of money. This is often called a liquidity preference. Three reasons bind to maintain liquidity, namely the motive for transactions, just in case and motive for speculation. One of the monetary policies carried out by the government is controlling money circulation and interest rates. If inflation occurs, the price of goods rises due to high demand and insufficient supply, then changes in interest rates (tend to increase interest rates), so that the money circulating in the community can be reduced and prices can return to balance again. Keynes said that the amount of money invested would increase if interest rates also increase (the horizontal axis is the amount of money spent, and the vertical axis is the interest rate) (Siahaan \& Hidayat, 2014).

The correlation of stock price movements with fluctuations in bank interest rates, in theory, will be inversely proportional. This means that if the interest rate increases, the share price as a commodity transaction on the stock exchange will decline because investors are more interested in shifting their investment in banking products such as deposits and so on. Conversely, if fluctuations in bank interest rates decrease, the stock price will rise because banking products are considered less profitable compared to stock investments (Jones, 1997).

The US Congress formed the Federal Reserve or the Fed in 1913. This institution is very independent. That is, the policy does not need to get approval from the US President. Periodically, Congress will evaluate the performance of the Fed. Like a central bank in other countries, The Federal Reserves (the Fed) have several main tasks. Banks throughout the United States (US), become banks for the US government 
and become regulators of financial institutions. Also, the Fed also has the authority to manage US monetary conditions. The difference is, compared to other central banks, the Fed's policies can affect financial markets throughout the world, including also to Indonesia ( www.federalreserveonline.org).

The BI Rate is a policy interest rate that reflects the monetary policy stance set by Bank Indonesia and is publicly announced. BI Rate announced by the Board of Governors of Bank Indonesia each meeting of the Board of Governors of monthly and implemented on monetary operations conducted by Bank Indonesia through the management of liquidity ( liquidity management ) in currency markets to achieve the operational target of monetary policy. The operational target of monetary policy is reflected in the development of Overnight Interbank Money Market (PUAB O / N) interest rates. The movement in the interbank rate is expected to be followed by developments in deposit rates, and turn bank lending rates. Considering other factors in the economy, Bank Indonesia will generally raise the BI Rate if future inflation is expected to exceed the set target, whereas Bank Indonesia will reduce the BI Rate if future inflation is expected to be below the set target. (www.bi.go.id) .

\subsection{Development of Hypotheses}

Before the development of the hypothesis, the researcher explained the thinking framework of this study that can be seen in Figure 3. The condition of the capital market in one region will be one of the considerations in making decisions to sell or buy for domestic investors and foreign investors. ASEAN capital markets consisting of the Indonesian Capital Market (with the IHSG-Composite Stock Price Index), Singapore (Straits Index-STI), Malaysia (Kuala Lumpur Stock Exchange IndexKLSE), Thailand (Stock Exchange of Thailand Index-SETI), and The Philippines (Philippines Stock Exchange Index-PSE) influences the decision to buy-sell shares by domestic and foreign investors, so the first step in this research is to test whether capital market cointegration occurs in the ASEAN region.

Next, this research conducted East Asian Capital Market cointegration tests consisting of Capital Markets in Japan (225 stock index issuers in Japan-NIKKEI225), 
Capital Markets in Hong Kong (33 stock indexes in HangSeng-HSI33), South Korea (Korea Composite Stock KOSPI Price Index ), Taiwan Capital Market (Taiwan Stock Exchange), and the China Capital Market (Shanghai Composite Index ). After carrying out the ASEAN Capital Market and East ASIA Capital Market cointegration tests, the effect of investment decision making (the decision to buy-sell shares) was tested by domestic and foreign investors.

This study also uses changes in US interest rates issued by the United States Central Bank (Federal Fund Rate- FFR) and the interest rates of the Central Bank of Indonesia (BI Rate) as variables that affect the decision to buy-sell shares in the Indonesian Capital Market both as investors Foreign and Domestic Investors. Therefore, the development of hypotheses can be briefly described as follows.

\subsubsection{ASEAN Capital Market Cointegration and East ASIA Capital Market}

\section{Cointegration}

The efficient market hypothesis theory (EHM) by Fama 1970 says information obtained from the price received is information attached to that price. If shares in ASEAN move positively because the ASEAN region is a region with an area of capital markets that has been partially integrated, then there is also a positive effect on the common stock index in Indonesia.

Dorodnykh (2014) conducted cointegration testing of 43 international capital markets (NYSE-Euronext, Nasdaq OMX Group, and MILVA) and European capital markets. The purpose of this study is to investigate the integration of global capital markets for the period 1995-2010 with multistage statistical data analysis consisting of the Johansen Cointegration Test and Multivariable Logit Model. The results obtained are still a little cointegration between the capital markets, but after more capital market cointegration has been grouped. Other findings in this study are known to be several variables that influence cointegration probabilities, namely: State, capital market size, financial regulation, cross-membership, demutualization, trading platform, and region. 
Karim and Majid (2010) re-examined the integration of capital markets and shortterm interactions between the Malaysian capital market and the American, Japanese, Singapore, Chinese and Thai capital markets. Data used weekly stock prices from January 1992 - May 2008. The results obtained there is a relationship/ cointegration of the Malaysian capital market with other capital markets. Factors that have significant influence are the proximity of geographical location and trade liberalization which has the consequence of reduced limits for investment and trade.

Therefore, the researcher made a hypothesis about capital market integration in ASEAN and East Asia as follows:

\section{H1a: There is cointegration in the ASEAN Capital Market (CSPI, STI, KLSE, SETI, PSE). \\ H2a: There is cointegration in the EAST ASIA Capital Market (NIKKEI, HSI, KOSPI, TWSE, SHCOMP).}

\section{2. 2. The Effect of ASEAN Capital Market Cointegration on the Decision of Transactions Buying and Selling Domestic and Foreign Investor Shares in Indonesia}

The efficient market hypothesis theory (EHM) by Fama 1970 forms a strong form, which says strong information can be obtained from historical data as well as publication data and private information when making a purchase-sell share decision that it already has.

Ameer (2006) tested the integration of six (6) ASEAN capital markets, namely the Indian, Indonesian, Malaysian, Pakistani, Korean and Thai capital markets. The data used is the capital market index of each country for the period January 1, 1990 31 December 2014. The method used is TARCH (Type of Auto-Regressive Conditional Heteroskedastic). The results obtained are the return and volatility spillover effect of the world and regional capital markets that affect the country's capital markets, except the Pakistan capital market.

Sari (2014) said the capital markets of the United States, Singapore, and Japan were integrated with the Indonesian capital market. Besides that, foreign portfolios 
and trade relations significantly influence the integration of the Indonesian capital market with its trading partner countries.

Therefore, the researcher made a hypothesis about the impact of capital market integration in ASEAN on the decision to buy and sell shares by foreign investors and domestic investors in the Indonesian Capital Market as follows:

\section{H2a: ASEAN Capital Market Cointegration (IHSG, STI, KLSE, SETI, PSE) affect the Decision of Buy-Sell Transactions of Foreign Investor Shares in the Indonesian Capital Market.}

H2b: ASEAN Capital Market Cointegration (IHSG, STI, KLSE, SETI, PSE) affect the Decision of Buy-Sell Transactions of Domestic Investors in the Indonesian Capital Market.

2.2.3. The Effect of East ASIA Capital Market Cointegration on Decision on Transaction T-Buy and Sell Domestic and Foreign Investor Shares in Indonesia

Karim \& Majid (2010) re-examined the integration of capital markets and short-term interactions between the Malaysian capital market and the American, Japanese, Singapore, Chinese and Thai capital markets. Data used weekly stock prices from January 1992 - May 2008. The results obtained there is a relationship/cointegration of the Malaysian capital market with other capital markets. Factors that have significant influence are the proximity of geographical location and trade liberalization which has the consequence of reduced limits for investment and trade.

Vasila (2013) researched with the aim of testing capital market integration. Submission is done by analyzing the volatility of spillover groups of stocks with high liquidity. The data used consisted of 40 French capital market shares, 100 British capital market shares, 30 German capital market shares, 25 Dutch capital market shares, 30 Swedish capital market shares, and 40 shares from the Italian capital market for the period January 1990 to April 2008 The results obtained show that in the European capital market there is strong integration between capital markets.

Agyei-Ampomah (2011) examined the linkages of African capital markets with regional and global capital markets for the period 1998 - 2007. The data tested 
were monthly returns for stocks using both local and US dollars. The results obtained by the African market are still segmented towards regional and global capital markets.

Therefore, the researcher hypothesized the impact of East ASIA integration on foreign and domestic investors on the decision to buy and sell shares in the Indonesian Capital Market as follows:

H3a: East ASIA Capital Market Cointegration (NIKKEI, HSI, KOSPI, SHCOMP, TWSE) influences the Decision of Buy-Sell Transactions of Foreign Investor Shares in the Indonesian Capital Market.

H3a: East ASIA Capital Market Cointegration (NIKKEI, HSI, KOSPI, SHCOMP, TWSE) influences the Decision of Buy-Sell Transactions of Domestic Investors in the Indonesian Capital Market.

\subsection{Effect of Federal Fund Rate and Bank Indonesia Rate Rate on Decision on \\ Buy-Sell Transactions of Domestic and Foreign Investor Stocks in Indonesia}

The Random Walk theory is considered the same as Market Efficiency Theory. There is a paradox of market efficiency that investors believe that a market is efficient, then the market will be inefficient because no one analyses the market (Bodie et al., 2008). But market efficiency depends on market participants who believe that markets are inefficient and trade securities to outperform the market. The market is not entirely efficient or inefficient. Almost all markets are efficient at some level, but there are also different ones. The market can experience a decline in market efficiency substantially because investors who have more knowledge can outperform less knowledgeable investors.

Siahaan \& Hidayat (2014) said that there is cointegration between the BI Rate and the Fed, using Johansen's cointegration, meaning that both interest rates have a long-run equilibrium relationship. His research also sought causality between the two interest rates using the Granger Causality. The result is that the Fed has an impact on interest rates at Bank Indonesia, but not vice versa. Bank Indonesia interest rates do not affect the Fed's interest rates.

Information that is often the material for selling and buying an investment in the capital market is one of the United States interest rate information. Even the issue of 
the Fed wants to increase interest rates already from the beginning of the month and the beginning of the year in 2015. Every time there is a meeting of The Federal, almost all exchanges have decreased (www.marketwatch.com). So that researchers formulate the problem as follows.

Therefore, the researcher made a hypothesis about the interest rate (FFR and BI rate) on the decision to buy and sell shares in the Indonesian Capital Market, for foreign investors and domestic investors as follows:

H4a: The Fed Fund Rate (FFR) and Bank Indonesia Rate (BIR) interest rates affect the Decision of Buy-Sell Transactions of Foreign Investor Shares in the Indonesian Capital Market.

H4b: The Fed Fund Rate (FFR) and the Bank Indonesia Rate (BIR) interest rates affect the Decision of the Investor's Domestic Buy-Sell Transactions in the Indonesian Capital Market.

2.2. 5. The Effect of ASEAN Capital Market Cointegration, East ASIA Capital Market, Interest Rates on the Transaction of Buying and Selling Domestic and Foreign Investor Stocks in Indonesia

The Random Walk theory produces data that is not stationary, but data that has long-term effects tend to have stationary data. Therefore, stationary data is data that can be used as a cointegration between capital markets in one adjacent area. However, the behavior of the movement of transactions in the capital market which is mainly due to the macroeconomics of each country makes each country have different buy and sell transactions (Sitinjak, 2013). Some market participants (rational investors) believe in market efficiency, but some belief in irrational market behavior, namely investors who trust their emotions more, then capital markets tend to be inefficient because nobody analyses the market (Bodie et al., 2008). Siahaan \& Hidayat (2014) used Johansen's cointegration; the results of the research said there is cointegration BI rate by the Fed. This means that both interest rates have equilibrium for the long term. Besides that, other results say the Fed has an impact on interest rates at Bank Indonesia (by using the Granger Causality), but the BI Rate does not affect the rate of interest of the Fed. 
Vasila (2013) researched with the aim of testing capital market integration. Submission is made by analyzing the volatility of spillover groups of stocks with high liquidity. The data used consisted of 40 French capital market shares, 100 British capital market shares, 30 German capital market shares, 25 Dutch capital market shares, 30 Swedish capital market shares, and 40 shares from the Italian capital market for the period January 1990 to April 2008 The results obtained show that in the European capital market there is strong integration between capital markets.

Agyei-Ampomah (2011) examined the linkages of African capital markets with regional and global capital markets for the period 1998 - 2007. The data tested were monthly returns for stocks using both local and US dollars. The results obtained by the African market are still segmented towards regional and global capital markets.

Therefore, the researcher made a hypothesis about ASEAN Capital Market Integration, East ASIA Capital Market, and interest rates (FFR and BI rate) on the decision to buy and sell shares in the Indonesian Capital Market, for foreign investors and domestic investors as follows:

H5a: ASEAN, East Asia Capital Market Integration, Fed Fund Rate (FFR) and Bank Indonesia Rate (BIR) interest rates affect the Decision of Buy-Sell Transactions of Foreign Investor Shares in the Indonesian Capital Market. H5b: ASEAN, East Asia Capital Market Integration, Fed Fund Rate (FFR) and Bank Indonesia Rate (BIR) interest rates affect the Decision of Buy-Sell Transactions of Domestic Investors in the Indonesian Capital Market.

\section{Research Method}

\subsection{Population and Samples}

The population in this study were companies included in the IDX index, STI index, KLSE index, SET index, PSE index, Nikkei index, HSI index, KOSPI index, SHCOMP index, and TWSE index (www.bloomberg.com; www.ojk.go.id). The method used for sampling is the purposive sampling method, which is a sampling method using specific criteria. The sampling criteria in this study were the decision to buy-sell shares by foreign and domestic investors during January 2014 to May 2016 from www.ojk.go.i d, and STI index data, KLSE index, SET index, Nikkei index, 
index Complete HSI was obtained from January 2014 to May 2016 from www.bloomberg.com and www.ojk .go.id. Sources of data in this study are the ASEAN Capital Markets index, EAST ASIA which can be downloaded at the address www.ojk.go.id. US Interest Rate may be downloaded at the address www.federalreserveonline.org, as well as Bank Indonesia interest rate level can be downloaded at the address www.bi.go.id. The type of data used is secondary data, namely data that is obtained indirectly through intermediary media (obtained and recorded by other parties).

\section{2. Research model}

There is also a research model that can be formulated in a formula such as the below:

$$
\begin{aligned}
& D M_{\text {Buy IA }}=\alpha_{1}+\beta_{1} \text { PM-ASEAN }+\varepsilon_{1} \\
& D M_{\text {Sell IA }}=\alpha_{2}+\beta_{2} \text { PM-ASEAN }+\varepsilon_{2} \quad \text {........... } 2 \\
& D M_{\text {Buy ID }}=\alpha_{3}+\beta_{3} \text { PM-ASEAN }+\varepsilon_{3} \quad \text {............. } \\
& D M_{\text {Sell ID }}=\alpha_{4}+\beta_{4} \text { PM-ASEAN }+\varepsilon_{4} \quad \text {............ } 4 \\
& D M_{\text {Buy IA }}=\alpha_{5}+\beta_{5} \text { PM-ASIATIM }+\varepsilon_{5} \\
& D M_{\text {Sell IA }}=\alpha_{6}+\beta_{6} \text { PM-ASIATIM }+\varepsilon_{6} \quad \text {........... } 6 \\
& D M_{\text {Buy ID }}=\alpha_{7}+\beta_{7} \text { PM-ASIATIM }+\varepsilon_{7} \quad \text {............ } 7 \\
& D M_{\text {Sell ID }}=\alpha_{8}+\beta_{8} \text { PM-ASIATIM }+\varepsilon_{8} \quad \text {........... } 8 \\
& D M_{\text {Buy IA }}=\alpha_{9}+\beta_{9} S B+\varepsilon_{10} \quad \text {........... } 9 \\
& D M_{\text {Sell ID }}=\alpha_{11}+\beta_{11} S B+\varepsilon_{11} \quad \text {.......... } 10 \\
& D M_{\text {Buy IA }}=\alpha_{12}+\beta_{12} \text { PM-ASEAN }+\beta_{12} \text { PM-ASIATIM }+\beta_{12} S B+\varepsilon \quad \text {......... } 11 \\
& D M_{\text {Sell IA }}=\alpha_{13}+\beta_{13} \text { PM-ASEAN }+\beta_{13} \text { PM-ASIATIM }+\beta_{13} S B+\varepsilon \quad \text {.......... } 12 \\
& D M_{\text {Buy ID }}=\alpha_{14}+\beta_{14} \text { PM-ASEAN }+\beta_{14} P \text { PM-ASIATIM }+\beta_{14} S B+\varepsilon \quad \text {.......... } 13 \\
& D M_{\text {Sell ID }}=\alpha_{15}+\beta_{15} \text { PM-ASEAN }+\beta_{15} \text { PM-ASIATIM }+\beta_{15} S B+\varepsilon \quad \text {......... } 14
\end{aligned}
$$

\section{Where:}

$\mathrm{DM}_{\text {Buy IA }}=$ Transaction Decision to Buy Foreign Investors

$\mathrm{DM}_{\text {Sell } \mathrm{IA}}=$ Transaction Decision Selling Foreign Investors

DM Buy IA = Decision on Buying Domestic Investors Transactions

DM SelliD= Domestic Investor Selling Transaction Decision

PM-ASEAN= ASEAN Capital Market Index (CSPI, STI, KLSE, SET, PSE)

PM-ASIATIM = Capital Market Index in East Asia (NIKKEI, HSI, KOSPI, SHCOMP, TWSE)

SB = Interest Rate (Bank of the United States and Bank Indonesia Interest Rate) 


\subsection{Operational definition}

Decision Making Decision on Foreign Investor Buy Transactions is an annual share purchase transaction conducted by foreign investors in the Indonesian Capital Market (data can be downloaded at www.ojk.go.id ). Decision Making Decision on Selling Foreign Investor Transactions is an annual sale of shares transactions carried out by foreign investors in the Indonesian Capital Market (data can be downloaded at www.ojk.go.id ). Decision Making Decision on Domestic Investor Buy Transactions is an annual share purchase transaction carried out by domestic investors in the Indonesian Capital Market (data can be downloaded at www.ojk.go.id). Decision Making Decision on Selling Domestic Investor Transactions is an annual share purchase transaction conducted by domestic investors in the Indonesian Capital Market (data can be downloaded at www.ojk.go.id ). The ASEAN Capital Market is calculated from the ASEAN Capital Market Index, CSPI, STI Index, KLSE Index, SET Index, PSE Index (data can be downloaded at www.ojk.go.id). The East Asia Capital Market is calculated from the Capital Market Index in East Asia, the NIKKEI Index, the HSI Index, the KOSPI Index, the SHCOMP Index, the TWSE Index (data can be downloaded at www.ojk.go.id). Interest rates are the annual interest rates of the American Central Bank (www.federalreserveonline.org) and the Central Bank of Indonesia Interest Rate ( www.bi.go.id).

\subsection{Hypothesis testing}

This research model was tested using EViews 9. In EViews 9 there are several tools used, namely stationary testing, cointegration testing, and hypothesis testing with t-tests and f- tests that are automatically calculated by EViews as well as coefficients (Stratz, 2015) Formula 1 to formula 14 still have variables that are random or stochastic or non-interconnected variants. Therefore, before the cointegration test is carried out, unit root testing is required (Root Test Unit). In this test, the data that was not stationary will become stationary with the first difference (first order). In the appendix, some labels use $\Delta \mathrm{X}$ or $\mathrm{DX}$, where $\mathrm{X}$ is the variable of this study. This stationary test can be said to be stationary if it does not contain a unit root, meaning at 
the first different level (significance $\alpha=5 \%$ ), the probability is $<0.05$. The cointegration test looks at the results of the trace test, testing the hypothesis that requires the number of cointegration directions less or equal to the coefficient (Gujarati, 2004; Siahaan \& Hidayat, 2014).

$$
\begin{aligned}
& p \lambda \operatorname{trace}(r)=-T \sum i=r+i \operatorname{Sin}(1-\lambda i) \\
& \lambda \max (r, r+1)=-T \operatorname{in}(1-\lambda r+1)
\end{aligned}
$$

Where:

$\lambda \mathrm{i}=\lambda_{\mathrm{r}+1} \ldots \lambda_{\mathrm{n}}$; is the smallest eigenvectors

$\mathrm{r}=$ cointegration vector

If the value of Trace Statistics is greater than Max-eigenvalue Statistic or (Formula 15 and 16) from Critical Value (Sing $\alpha=5 \%$ ), then there will be cointegration. This cointegration test is to show a long-term relationship. After testing stationary and cointegration, then testing the hypothesis with T-Test and F-Test. Acceptance of hypotheses if the probability of the value of T-Test or value of F-Test is less than $\alpha$ $10 \%$ and $5 \%$.

\section{Discussion of Result}

\subsection{Data analysis}

Variable used in this study, in the form of index variables ASEAN countries (JCI, STI, KLSE, SETI, PSE), EAST ASIA (NIKKEI, HSI, KOSPI, TWSE, SHCOMP), as well as the interest rate the Fed (Federal Fund Rate), and the Bank Indonesia interest rate (BI Rate). The Capital Market Index in ASEAN each shows data (CSPI, STI, KLSE, SETI, PSE) have an average above the standard deviation, meaning that changes in the index do not move in a variety of ways (can be seen in Figure 2) The ASEAN Capital Market Index data shows almost the same pattern of movement, so it can be said that the tendency to have a relationship in the long run. The five ASEAN Capital Markets have a minimum value of 1264.07 in the Thai Capital Market (SETI) and a maximum amount of 7940.49 in the Philippine Capital Market (PSE). These five capital market indices have an index movement average of 3667.36 with a standard deviation of around 89.12 to 449.83. That is, the ASEAN Capital Market (CSPI, STI, 
KLSE, SETI, PSE) still has the opportunity to optimize the movement of its stock transactions.

The most significant opportunity seen from the ASEAN Capital Market data is the Thai Capital Market (SETI), then the Kuala Lumpur Malaysia Capital Market (KLSE), and finally the Singapore Capital Market (STI). The researcher looked at the magnitude of the index during the research observation period (January 2014 to May 2016), which was the most suitable ASEAN Capital Market index if synergic cooperation was carried out for the long term. Also, the smallest standard deviation is the Kuala Lumpur Malaysia Capital Market (KLSE) of 89.12. This means that KLSE has a lower risk of index fluctuation compared to the fluctuations in the Philippine Capital Market index $(\mathrm{STD}=449.83)$.

The ASEAN capital market which is amid its development since 2014 (January) until 2016 (May) is the Indonesian Capital Market, has a fairly good movement (seen from the Mean $=4884.03 ;$ STD $=320.61)$. Also, domestic investors increased the amount of their contribution (conducting share buy-sell transactions) compared to foreign investors (61\% of domestic investors, 39\% of foreign investors).

The Capital Market Index in East Asia which consists of the NIKKEI index, HSI, KOSPI, TWSE, SHCOMP has a standard deviation smaller than the average, meaning that changes in the East Asia Capital Market index are not very varied. However, at a particular time in the fourth quarter of 2014, as well as the first quarter of 2015 there was a significant change in change. Some of the things that caused the turmoil in the SHCOMP Index were the influence of the Fed's stimulus as well as the value of the Yuan Currency devalued, and some events that the Chinese themselves felt there was a gradual movement of shares. The value of the Chinese currency has been reduced in value against foreign currencies (precisely on 11 August 2015). The volatility of change was also quite significant during the first quarter and entering the second quarter of 2016; the Taiwan Capital Market rebounded by 1.5\% (precisely on June 27, 20016) (www.market.bisnis.com).

The most significant opportunity seen from the descriptive data of the Eastern Asia Capital Market statistics is the South Korean Capital Market (KOSPI Index), 
then the Chinese Capital Market (SHCOMP), and finally the Taiwan Capital Market (TWSE). Researchers in the movement of the index from January 2014 to May 2016 had a full change of action for the Taiwan Capital Market (TWSE) and the Chinese Capital Market (SHCOMP) having a standard deviation of the range 507.71 to 768.24 (successive quantities). That is, the risks faced by shareholders will be higher than the uncertainties in the Capital Market in ASEAN. The highest Hong Kong Capital Market Index (HSI) $($ MAX = 28133) and riskiest (SDV = 2131.86) compared to other East ASIA Capital Market indices. This means that HSI has high returns with high risks to be borne.

The Federal Fund Rate and the Bank Indonesia interest rate (BI Rate) have very significant differences in percentage. The Fed (Federal Fund Rate) has a change between $0.07 \%$ and $0.38 \%$, while the BI Rate has a range of changes from $6.75 \%$ to 7.75\% (January 2014 to May 2016). This is due to the value of the US Dollar Currency with the Indonesian Rupiah Currency value is very different, around Rp13,151.00 per USD (IDR / USD) (www.bi.go.id, July 12, 2016, at 15.30WIB).

\subsection{Stationarity Test}

Capital market index data tends to have a random-walk change, the time series data produced does not tend to be stationary, so the data used is stationary in other words it will be free from autocorrelation problems. Data can be said to be stationary if the time series data does not experience systematic changes in the long run. The following are stationarity tests based on each capital market and capital market index on the buying and selling decisions of foreign investors and domestic investors.

\subsubsection{ASEAN Capital Market Stationarity Test on Transaction Purchase Decisions}

\section{Selling Domestic Investors and Foreign Investors}

In table 1 the results of the unit root test summary can be seen using the Augmented Dickey-Fuller Test (ADF- Test). This ADF test was developed from the DF- Test. This ADF- Test model shows the overall stationary ASEAN Capital Market index variables. Data before being tested stationary there was a movement for 29 
months (research observations January 2014 to May 2 016). There are fluctuations in the index in the Indonesian Capital Market, Malaysian Capital Market, Singapore Capital Market, Thai Capital Market, and the Philippine Capital Market. The pattern is almost the same. Therefore the graph results are retested with the ADF-Test, so the result is the ASEAN Capital Market stationary.

4.2.2. East Asia Capital Market Stationarity Test on the Decision of Domestic Investor and Buy-Sell Transactions

In table 2 the results of the unit root test summary can be seen using the Augmented Dickey-Fuller Test (ADF- Test). This ADF- Test shows the overall stationary East ASIA Capital Market index variables. There looks subjectively pattern of the rise and fall in the capital market index such as the East Asia Japan Capital Markets, Capital Markets Hong Kong, China Capital Markets, Capital Markets Taiwan movement patterns are almost the same. However, the pattern of South Korean Capital Market movements is not as dynamic as the movements of other East ASIA Capital Markets. This can be overcome by formally testing the ADFTest. Therefore, the initial condition of the data before being stationary, then the ADF is formally tested; the result is stationary.

\subsubsection{Interest Rate Stationary Test (BI Rate and Fed) on Decisions of Domestic} Investor and Buy-Sell Transactions

In table 3 the results of the unit root test summary can be seen using the Augmented Dickey-Fuller Test (ADF- Test). This ADF- Test shows the overall variable Interest Rate Federal Fund Rate (FFR) and Bank Indonesia Interest Rate (BI Rate) are stationary. These results are also supported by previous studies (Siahaan \& Hidayat, 2014) which say the Fed and the BI rate have stationary data.

\subsubsection{ASEAN Capital Market Stationarity Test, East ASIA Capital Market, and} Interest Rate (BI Rate and Federal Fund Rate)

In table 4 you can see the results of the unit root test summary using the Augmented Dickey-Fuller Test (ADF- Test). This ADF- Test shows all ASEAN 
Capital Market index variables (CSPI, KLSE, STI, SETI, PSE), East Asia Capital Markets (NIKKEI, HSI, KOSPI, TWSE, SHCOMP) and Interest Rates (FFR \& BIR) are stationary. Stationary tests for ASEAN Capital Markets, East Asia and Interest Rates on Decisions of Buy Transactions by Foreign Investors occur at first difference. Likewise, for the Decision of Sale and Buy Transactions by Domestic Investors.

\subsection{Cointegration Test}

Cointegration is very important to get a long-term balance relationship. The results of the ASEAN and East Asia Capital Market cointegration can be seen below.

\subsubsection{ASEAN Capital Market Cointegration}

The ASEAN Capital Market co-integration test results of ASEAN Capital (IHSG, KLSE, STI, SETI, PSE) can be seen in Table 5. In the cointegration test with Johansen's Multivariate, the Trace Statistic results have a greater value than the Critical Value (with $\alpha=5 \%$; prob. 0.0200). This means that the ASEAN Capital Market has cointegration or equilibrium conditions in the long run, then Hypothesis 1a is accepted. This cointegration result can provide an overview for future estimates regarding the joining of the ASEAN Capital Market with several leading issuers of each ASEAN country. The Indonesian Capital Market has already indexed IDX-30, which contains the 30 best shares of the IDX version. Researchers see the issuers listed in IDX-30 as issuers in LQ45, meaning liquid issuers are issuers entrusted to be transacted in the ASEAN Capital Market. The same goes for the other ASEAN Capital Markets, Singapore, Malaysia, Thailand and Philippine.

\subsubsection{EAST ASIA Capital Market Cointegration}

The results of the Eastern Asia Capital Market cointegration test (NIKKEI, HSI, KOSPI, TWSE, SHCOMP) can be seen in Table 6. The Johansen cointegration test results show that the Trace Statistic value is greater than the Critical Value $(\alpha=$ 5\%; prob. 0.0241). This means that the East Asia Capital Market has cointegration or 
equilibrium conditions in the long run, so Hypothesis $1 \mathrm{~b}$ is accepted. This cointegration result provides another perspective regarding the joining of each capital market based on the geographical proximity and agreement of each existing capital market law if it merges the East ASIA Capital Market and the ASEAN Capital Market by containing the best issuers from each country. This also gave enlightenment to foreign investors and domestic investors in Indonesia to begin exploring stock investments in ASEAN and East Asia countries.

\subsubsection{Interest Cointegration}

The results of the interest rate cointegration test (FFR and BIR) can be seen in Table 7. This cointegration test is carried out on each of the FFR and BIR variables at first difference. The result is that the Trace Statistic value is greater than the Critical Value. This means that there is long-term cointegration or in other words a longterm equilibrium relationship. This result is supported by previous research by Siahaan \& Hidayat (2014), showing a cointegration test with Johansen's Multivariate between the Fed and the BI Rate, and the Fed having an impact on the BI Rate. This means that the Fed's ups and downs also have an impact on the rise and fall of the BI rate, not vice versa.

\subsection{Hypothesis testing}

4.4.1. ASEAN Capital Market Cointegration affects the Decision of Domestic Investor and Buy-Sell Transactions

The previous results (table 5) indicate the existence of cointegration for the ASEAN Capital Market, namely the long-term equilibrium relationship for the Capital Market in Indonesia, Malaysia, Singapore, Thailand and Philippine. The next stage in this research is what variables are most influential in conducting buy and sell transactions for foreign investors in Indonesia. In table 8, you can see the results of the F test, the result of a sale transaction by a domestic investor (Sig. $\alpha=10 \%$; Prob. 0.091). This means that the development indices in the capital markets in ASEAN (Indonesia, Malaysia, Singapore, Thailand, and Philippine) have an impact on stock 
selling transactions by domestic investors in Indonesia. However, which capital market is the most influential in carrying out this sale transaction.

Processed other statistics, shows the Malaysian Capital Market which has a significant positive effect on the ASEAN Capital Market selling transactions. This means that ASEAN Capital Market cointegration has a significant positive impact (Sig. $\alpha=10 \%$; Prob. 0.095) on selling transactions for domestic investors in Indonesia. While foreign investors in the Indonesian Capital Market also have a significant positive result for buy transactions (Sig. $\alpha=10 \%$; Prob. 0.068) in the Malaysian Capital Market (KLSE). However, the transaction of Singapore Capital Market (STI) for foreign investors has a significant negative effect (Sig. A = 5\%; Prob. 0.022). This means that the Cointegration of the ASEAN Capital Market is more likely to influence sales transactions than buying transactions by foreign and domestic investors. Domestic investors can see developments in the Malaysian Capital Market (KLSE) and Singapore Capital Market (STI) first if they want to do a stock portfolio in the ASEAN Capital Market.

\subsubsection{EAST ASIA Capital Market Cointegration affects the Decision of Domestic} Investor and Buy-Sell Transactions

The East Asia Capital Market consisting of the Japanese Capital Market (NIKKEI), Hong Kong Capital Market (HSI), South Korea Capital Market (KOSPI), China Capital Market (SHCOMP), and Taiwan Capital Market (TWSE). In table 9 the results of Test-F say that the sale transaction by domestic investors is significant (Sig. $\alpha=10 \%$; Prob. 0.059). This means that the development of the index in the capital market in East Asia has an impact on stock selling transactions by domestic investors in Indonesia. However, which East ASIA capital market is the most influential in making this sale transaction.

Processed other statistics, the Taiwan Capital Market which has a significant positive effect (Sig. A $=5 \%$; Prob. 0.043) on selling transactions in the East Asia Capital Market. This means that the East Asia Capital Market cointegration has a significant positive effect on selling transactions for domestic investors in Indonesia. 
However, the decisions of foreign investors in the Indonesian Capital Market to buying and selling transactions are not significant. This means that Cointegration East ASIA Capital Market is more likely to influence sales transactions than buying transactions by domestic investors. Domestic investors can see the development of the Taiwan Capital Market (TWSE) first if they want to do a stock portfolio in the East Asia Capital Market.

\subsubsection{Interest Cointegration (BI Rate and Federal Fund Rate) for Decisions of}

\section{Domestic Investor and Buy-Sell Transactions}

Interest rate cointegration is very different from capital market cointegration. Cointegration here uses the first difference, meaning there is a difference between the Fed interest rate (FFR) and the Bank Indonesia interest rate (BIR). However, the results of this study (F-Test) show that the movement of FFR and BIR interest rates has a significant positive effect on the decision to buy stock investments by foreign investors (Sig. $\alpha=10 \%$; Prob. 0.074) and domestic investors (Sig. $\alpha=10 \%$; Prob. 0.095) in the ASEAN Capital Market and the East ASIA Capital Market (Table 10). That is, the development of the Fed and Bank Indonesia interest rates (BI Rate) has an impact on stock buying transactions by foreign and domestic investors in Indonesia, so Hypothesis $4 \mathrm{a}$ and $4 \mathrm{~b}$ Hypothesis are accepted.

Processed other statistics, the movements of the Fed and BI Rate interest rates have a significant negative effect on buying transactions by foreign investors (Sig. $\alpha=$ 5\%; Prob. 0.045) and domestic investors (Sig. $\alpha=5 \%$; Prob. 0.042). That is, the movement of the Fed's interest rates and the BI Rate drops, so the reaction of foreign and domestic investors will make transactions to buy shares in the Indonesian Capital Market. The decision of selling transactions for domestic investors in Indonesia was also significantly negative (Sig. $\alpha=5 \%$; Prob. 0.039). However, investor selling decisions by foreign investors in the Indonesian Capital Market have no significant effect. That is, Domestic investors can see the development of the fluctuations in the Fed's interest rates and the BI Rate first if you want to buy and sell transactions in the Indonesian Capital Market. 


\subsubsection{ASEAN Capital Market Cointegration, East Asia Capital Market, and Interest} Rates on Decisions on Domestic Investor and Buy-Sell Transactions

In table 8, there is no significant $\mathrm{F}$ test, meaning that cointegration for the ASEAN Capital Market, East Asia, and the Interest Rate cannot be tested, even though the cointegration results show that equilibrium can occur in the long run. In table 15 there is no significant $\mathrm{F}$ test, but the $\mathrm{T}$-Test has a significant positive effect, namely the Philippine Capital Market (Sig. $\alpha=10 \%$; Prob.

0.075) and the Taiwan Capital Market (Sig. A = 5\%; Prob. 0.012) affect sales transactions by domestic investors in Indonesia. However, there is also a significant negative effect, namely the Indonesian Capital Market (CSPI) (Sig. $\alpha=5 \%$; Prob. 0.049), South Korean Capital Market (KOSPI) (Sig. $\alpha=10 \%$; Prob. 0.029), and The Chinese Capital Market (SHCOMP) (Sig. $\alpha=5 \%$; Prob. 0.014) has an effect on selling transactions by domestic investors in Indonesia. This means that cointegration for the ASEAN, East Asia, and Interest Rate Capital Markets affects sales transactions.

\section{Conclusions, Implications, and Limitation}

Based on the previous discussion, there are several conclusions, namely: a cointegration in the ASEAN Capital Market consisting of the Indonesian Capital Market (IHSG), Singapore Capital Market (STI), Malaysian Capital Market (KLSE), Thai Capital Market (SET), and Markets Philippine Capital (PSE). There is cointegration in the East Asia Capital Market consisting of the Japanese Capital Market (NIKKEI), Hong Kong Capital Market (HSI), South Korea Capital Market (KOSPI), China Capital Market (SHCOMP), and Taiwan Capital Market (TWSE). There is Cointegration of the United States Central Bank (Federal Fund Rate) with the Interest Rate of the Central Bank of Indonesia (BI Rate). Domestic Investors decide to buy shares to see the movement of Interest Rates Central Bank of the United States (the Federal Funds rate) and the interest rate of the Central Bank of Indonesia (BI Rate). Domestic investors decide to sell shares by looking at the movement of the index in the ASEAN Capital Market (KLSE and STI Index) and the East Asia Capital Market (TWSE Index). Foreign investors decided to buy shares in Indonesia to see the 
movement of Interest Rates Central Bank of the United States (the Federal Funds rate) and the interest rate of the Central Bank of Indonesia (BI Rate).

Further Research Suggestions and Implications. Capital markets law in each each country has an individual legal force in the country, but at the time of capital market integration in both the ASEAN and East Asia need to be socialized again to the capital market participants. Domestic investors can stretch their portfolios to the capital markets in ASEAN and East Asia, by seeing equilibrium between capital markets in the long term which is quite good. The limitations of this study have not yet been able to provide recommendations on the weight of an efficient portfolio for each portfolio of domestic stocks and ASEAN shares or East Asian shares. However, the researcher can advise that the stock portfolio owned by domestic and foreign individual investors can begin to collect shares in the integrated capital market.

\section{REFERENCE}

Asian Development Bank Institute (2014). ASEAN 2030 Toward Borderless Economic Community.

Association of Southeast Asian Nations (2014). Asean Economic Community Blueprint.

Fama, Eugene F. (1970). Efficient Capital Markets: A Review of Theory and Empirical Work. The Journal of Finance, Vol. 25, No. 2, Papers and Proceedings of the Twenty-Eighth Annual Meeting of the American Finance Association New York, N.Y. December 28-30, 1969 (May 1970), pp. 383-417.

Gujarati (2004). Basic Econometrics. $4^{\text {th }}$ Edition-McGraw-Hill Comp.

Kahneman, D., \& Twersky, A. (1979). Prospect theory: An analysis of decision under risk.Econometrica, 47(2), 263-291.

Kahneman, D., \& Twersky, A. (2002). Maps of bounded rationality: A perspective on intuitive Judgment and choice. Prize Lecture, 8 December in Princeton University, Department of Psychology, Princeton, USA.

Kowanda, Dionysia, Sugiharti Binastuti, Rowland Bismark Fernando Pasaribu, \& Marina Ellim (2014). Pengaruh Bursa Saham Global, ASEAN, dan Harga Komoditas terhadap IHSG danNilaiTujar EUR/ USD. Jurnal Akuntansi \& Manajemenol. 25, No,2 Agustus, pp. 79-88. 
Rahman, Arif Budi (2011). ASEAN EXCHANGE DAN PROSPEK INTEGRASI PASAR FINANSIAL KAWASAN (CatatanHasilPertemuan ASEAN Finance Ministers Meeting, Bali, 8 April 2011).

Sari, Kartika (2014). Analisis Faktor-Faktor Pendorong Integrasi Pasar Modal Indonesia.Skripsi Tidak dipublikasikan oleh Fakultas Ekonomi dan Bisnis Universitas Brawijaya Malang.

Siahaan, Lasma Melinda \& Hidayat, Paidi (2014). AnalisisKausalitasdanKointegrasiantara Tingkat SukuBunga Bank Indonesia (BI Rate) denganSukuBunga Bank Amerika Serikat (The Fed). JurnalEkonomidanKeuangan Vol. 1 No.8.

Sitinjak, Elizabeth Lucky Maretha (2013). Perilaku Inestor Individu dalam Pembuatan Keputusan Investasi Saham: Efek Disposisi dan Informasi Akuntansi. JurnalOrganisasidanManajemen, Vol 9, No.1, Maret, pp. 31-53.

Sitinjak, E.L. Maretha, Y. Warastuti, H.S. Sulistyanto (2014). Earnings Per Share, Book Value Equity, dan Cash Flow Operation pada Buy Hold Abnormal

Return Primary Trend Saham LQ-45 (Periode 2010-2012). JurnalAkuntansiBisnis, Vol.13, No.25, pp. 44-62.

Singh, Datuk Ranjit (2008). ASEAN Capital Market Integration Issues and Challenges.

Stratz, Richard (2015). Eviews Illustrated for Version 9. The University of California-Santa Barbara.

OtoritasJasaKeuangan (2016). StatistikPasar Modal: StatistikMinggu ke-4 Mei 2016. (be downloaded at www.ojk.go.id).

(2015). StatistikPasar Modal: StatistikMinggu ke-4 Desember 2015. (be downloaded at www.ojk.go.id).

(2014). StatistikPasar Modal: StatistikMinggu ke-4 Desember 2014. (be downloaded at www.ojk.go.id). 


\section{APPENDIX}

Table 1.

Summary of ASEAN Capital Market Stationarity Test Results

\begin{tabular}{|c|c|c|c|}
\hline INFORMATION & $\begin{array}{c}\text { Augmented Dickey- } \\
\text { Fuller (ADF-Test) }\end{array}$ & $\begin{array}{c}\text { Prob. } \\
\alpha=5 \%\end{array}$ & RESULT \\
\hline PM ASEAN-> DM BUY FOREIGN & 29.814 & 0.003 & Stasioner \\
\hline PM ASEAN-> DM SELL FOREIGN & 38.447 & 0.000 & Stasioner \\
\hline PM ASEAN-> DM BUY DOMESTIC & 28.054 & 0.005 & Stasioner \\
\hline PM ASEAN-> DM SELL DOMESTIC & 27.427 & 0.007 & Stasioner \\
\hline
\end{tabular}

Source: Eviews-9 Processed Data

Table 2.

Summary of East Asian Capital Market Stationary Test Results

\begin{tabular}{|l|c|c|c|}
\hline \multicolumn{1}{|c|}{ INFORMATION } & $\begin{array}{c}\text { Augmented Dickey- } \\
\text { Fuller (ADF-Test) }\end{array}$ & $\begin{array}{c}\text { Prob. } \\
\alpha=5 \%\end{array}$ & RESULT \\
\hline $\begin{array}{l}\text { PM ASIA TIMUR-> DM BUY } \\
\text { FOREIGN }\end{array}$ & 67.732 & 0.000 & Stasioner \\
\hline $\begin{array}{l}\text { PM ASIA TIMUR-> DM SELL } \\
\text { FOREIGN }\end{array}$ & 27.309 & 0.007 & Stasioner \\
\hline $\begin{array}{l}\text { PM ASIA TIMUR-> DM BUY } \\
\text { DOMESTIC }\end{array}$ & 49.613 & 0.000 & Stasioner \\
\hline $\begin{array}{l}\text { PM ASIA TIMUR-> DM SELL } \\
\text { DOMESTIC }\end{array}$ & 60.124 & 0.000 & Stasioner \\
\hline
\end{tabular}

Source: Eviews-9 Processed Data

Table 3.

Summary of Interest Rate Stationary Test Results

\begin{tabular}{|l|c|c|c|}
\hline \multicolumn{1}{|c|}{ INFORMATION } & $\begin{array}{c}\text { Augmented Dickey- } \\
\text { Fuller (ADF-Test) }\end{array}$ & $\begin{array}{c}\text { Prob. } \\
\alpha=5 \%\end{array}$ & RESULT \\
\hline BI RATE-> DM BUY FOREIGN & 37.844 & 0.000 & Stasioner \\
\hline BI RATE -> DM SELL FOREIGN & 20.343 & 0.002 & Stasioner \\
\hline BI RATE -> DM BUY DOMESTIC & 33.964 & 0.000 & Stasioner \\
\hline BI RATE -> DM SELL DOMESTIC & 44.849 & 0.000 & Stasioner \\
\hline
\end{tabular}

Source: Eviews-9 Processed Data 
Table 4.

Summary of ASEAN Capital Market, East Asia, and Interest Rate Test Stationarity

\begin{tabular}{|l|c|c|c|}
\hline \multicolumn{1}{|c|}{ INFORMATION } & $\begin{array}{l}\text { Augmented } \\
\text { Dickey- } \\
\text { Fuller } \\
\text { (ADF-Test) }\end{array}$ & $\begin{array}{l}\text { Prob. } \\
\alpha=5 \%\end{array}$ & RESULT \\
\hline $\begin{array}{l}\text { PM ASEAN, PM ASIA TIMUR, SUKU } \\
\text { BUNGA-> DM BUY FOREIGN }\end{array}$ & 163.635 & 0.000 & Stationer \\
\hline $\begin{array}{l}\text { PM ASEAN, PM ASIA TIMUR, SUKU } \\
\text { BUNGA-> DM SELL FOREIGN }\end{array}$ & 45.452 & 0.010 & Stationer \\
\hline $\begin{array}{l}\text { PM ASEAN, PM ASIA TIMUR, SUKU } \\
\text { BUNGA-> DM SELL DOMESTIC }\end{array}$ & 120.918 & 0.000 & Stationer \\
\hline $\begin{array}{l}\text { PM ASEAN, PM ASIA TIMUR, SUKU } \\
\text { BUNGA-> DM BUY DOMESTIC }\end{array}$ & 170.641 & 0.000 & Stationer \\
\hline
\end{tabular}

Source: Eviews-9 Processed Data

Table 5.

ASEAN PM Cointegration Test Results

Series: LNIHSG LNKLSE LNPSE LNSETI LNSTI

Lags interval (in first differences): 1 to 1

Unrestricted Cointegration Rank Test (Trace)

\begin{tabular}{ccccc}
\hline \hline $\begin{array}{c}\text { Hypothesized } \\
\text { No. of CE(s) }\end{array}$ & Eigenvalue & $\begin{array}{c}\text { Trace } \\
\text { Statistic }\end{array}$ & $\begin{array}{c}0.05 \\
\text { Critical Value }\end{array}$ & Prob. $^{* *}$ \\
\hline \hline None & & & & \\
At most 1 & 0.725305 & 74.52665 & 69.81889 & 0.0200 \\
At most 2 & 0.555681 & 39.64016 & 47.85613 & 0.2356 \\
At most 3 & 0.158686 & 17.73741 & 29.79707 & 0.5855 \\
At most 4 & 0.012306 & 4.999674 & 15.49471 & 0.8089 \\
\hline \hline
\end{tabular}

Trace test indicates 1 cointegrating eqn(s) at the 0.05 level

* denotes rejection of the hypothesis at the 0.05 level

${ }^{* *}$ MacKinnon-Haug-Michelis (1999) p-values 
The Indonesian Journal of Accounting Research - Jan, Vol. 22 , No.1, 2019

Table 6.

Cointegration Test Results for East ASIA PM

Series: LNNIKKEI LNKOSPI LNHSI LNSHCOMPD LNTWSED

Lags interval (in first differences): 1 to 1

Unrestricted Cointegration Rank Test (Trace)

\begin{tabular}{ccccc}
\hline \hline $\begin{array}{c}\text { Hypothesized } \\
\text { No. of CE(s) }\end{array}$ & Eigenvalue & $\begin{array}{c}\text { Trace } \\
\text { Statistic }\end{array}$ & $\begin{array}{c}0.05 \\
\text { Critical Value }\end{array}$ & Prob. $^{* *}$ \\
\hline \hline None & 0.676258 & 73.62125 & 69.81889 & 0.0241 \\
At most 1 & 0.562537 & 44.29823 & 47.85613 & 0.1039 \\
At most 2 & 0.464582 & 22.80238 & 29.79707 & 0.2559 \\
At most 3 & 0.217531 & 6.559961 & 15.49471 & 0.6293 \\
At most 4 & 0.006981 & 0.182146 & 3.841466 & 0.6695 \\
\hline \hline
\end{tabular}

Trace test indicates 1 cointegrating eqn(s) at the 0.05 level

* denotes rejection of the hypothesis at the 0.05 level

**MacKinnon-Haug-Michelis (1999) p-values

Table 7.

Summary of Interest Rate Cointegration Test Results

Unrestricted Cointegration Rank Test (Trace)

\begin{tabular}{|c|c|c|c|c|}
\hline $\begin{array}{c}\text { Hypothesized } \\
\text { No. of CE(s) }\end{array}$ & Eigenvalue & $\begin{array}{c}\text { Trace } \\
\text { Statistic } \\
\end{array}$ & $\begin{array}{l}0.05 \\
\text { Critical Value }\end{array}$ & Prob.** \\
\hline None * & 0.361527 & 16.90671 & 15.49471 & 0.0305 \\
\hline At most 1 * & 0.273714 & 7.035849 & 3.841466 & 0.0080 \\
\hline \multicolumn{5}{|c|}{$\begin{array}{l}\text { Trace test indicates } 2 \text { cointegrating eqn(s) at the } 0.05 \text { level } \\
\text { * denotes rejection of the hypothes is at the } 0.05 \text { level } \\
\text { ** MacKinnon-Haug-Michelis (1999) p-values }\end{array}$} \\
\hline \multicolumn{5}{|c|}{ Unrestricted Cointegration Rank Test (Maximum Eigenvalue) } \\
\hline $\begin{array}{l}\text { Hypothesized } \\
\text { No. of CE(s) }\end{array}$ & Eigenvalue & $\begin{array}{c}\text { Max-Eigen } \\
\text { Statistic }\end{array}$ & $\begin{array}{c}0.05 \\
\text { Critical Value }\end{array}$ & Prob.** \\
\hline None & 0.361527 & 9.870860 & 14.26460 & 0.2205 \\
\hline At most 1 * & 0.273714 & 7.035849 & 3.841466 & 0.0080 \\
\hline
\end{tabular}

Max-eigenvalue test indicates no cointegration at the 0.05 level

* denotes rejection of the hypothes is at the 0.05 level

** MacKinnon-Haug-Michelis (1999) p-values 
Table 8.

Summary of F-Test for Buy-Sell Transactions of Foreign-Domestic Investors in the ASEAN Capital Market

\begin{tabular}{|c|c|c|c|c|}
\hline ASEAN CM & $\begin{array}{c}\text { F- } \\
\text { Statistic }\end{array}$ & Prob. & $\begin{array}{c}\text { Adj. } \\
\text { R- } \\
\text { Squared }\end{array}$ & $\begin{array}{c}\text { Durbin- } \\
\text { Watson } \\
\text { Stat. }\end{array}$ \\
\hline $\begin{array}{c}\text { Transactions } \\
\text { Buy Foreign } \\
\text { Investors }\end{array}$ & 1.917 & 0.130 & 0.141 & 2.123 \\
\hline $\begin{array}{c}\text { Transactions } \\
\text { Sell Foreign } \\
\text { Investors }\end{array}$ & 1.460 & 0.241 & 0.076 & 2.673 \\
\hline $\begin{array}{c}\text { Transactions } \\
\text { Buy } \\
\text { Domestic } \\
\text { Investors }\end{array}$ & 1.418 & 0.255 & 0.069 & 1.913 \\
\hline $\begin{array}{c}\text { Transactions } \\
\text { Sell } \\
\text { Domestic } \\
\text { Investors }\end{array}$ & 2.184 & 0.091 & 0.175 & 1.910 \\
\hline
\end{tabular}

Table 9.

Summary of F-Test for Buy-Sell Transactions of Foreign-Domestic Investors in the East Asia Capital Market

\begin{tabular}{|l|c|c|c|c|}
\hline $\begin{array}{l}\text { ASIA TIMUR } \\
\text { CM }\end{array}$ & $\begin{array}{c}\text { F- } \\
\text { Statistic }\end{array}$ & Prob. & $\begin{array}{c}\text { Adj. } \\
\text { R- } \\
\text { Squared }\end{array}$ & $\begin{array}{c}\text { Durbin- } \\
\text { Watson } \\
\text { Stat. }\end{array}$ \\
\hline $\begin{array}{l}\text { Transactions } \\
\text { Buy Foreign } \\
\text { Investors }\end{array}$ & 1.319 & 0.291 & 0.054 & 1.895 \\
\hline $\begin{array}{l}\text { Transactions } \\
\text { Sell Foreign } \\
\text { Investors }\end{array}$ & 0.674 & 0.647 & -0.062 & 2.717 \\
\hline $\begin{array}{l}\text { Transactions } \\
\text { Buy } \\
\text { Domestic } \\
\text { Investors }\end{array}$ & 0.500 & 0.773 & -0.102 & 2.615 \\
\hline $\begin{array}{l}\text { Transactions } \\
\text { Sell } \\
\text { Domestic } \\
\text { Investors }\end{array}$ & $\mathbf{2 . 5 3 1}$ & $\mathbf{0 . 0 5 9}$ & $\mathbf{0 . 2 2 1}$ & $\mathbf{2 . 7 1 4}$ \\
\hline
\end{tabular}


Table 10.

Summary of F-Test for Buy-Sell Transactions of Foreign-Domestic InvestorsInterest Rate

\begin{tabular}{|l|c|c|c|c|}
\hline \multicolumn{1}{|c|}{$\begin{array}{c}\text { ASEAN } \\
\text { CM }\end{array}$} & $\begin{array}{c}\boldsymbol{F} \text { - } \\
\text { Statistic }\end{array}$ & Prob. & $\begin{array}{c}\text { Adj. } \\
\text { R- } \\
\text { Squared }\end{array}$ & $\begin{array}{c}\text { Durbin- } \\
\text { Watson } \\
\text { Stat. }\end{array}$ \\
\hline $\begin{array}{l}\text { Transactions } \\
\text { Buy Foreign } \\
\text { Investors }\end{array}$ & 2.875 & 0.074 & 0.118 & 1.581 \\
\hline $\begin{array}{l}\text { Transactions } \\
\text { Sell Foreign } \\
\text { Investors }\end{array}$ & 0.321 & 0.728 & -0.060 & 2.298 \\
\hline $\begin{array}{l}\text { Transactions } \\
\text { Buy } \\
\text { Domestic } \\
\text { Investors }\end{array}$ & 2.579 & 0.095 & 0.101 & 1.692 \\
\hline $\begin{array}{l}\text { Transactions } \\
\text { Sell } \\
\text { Domestic } \\
\text { Investors }\end{array}$ & 2.457 & 0.105 & 0.094 & 1.666 \\
\hline
\end{tabular}

Table 11

Summary of F-Test for Buy-Sell Transactions of Foreign-Domestic Investors in the ASEAN Capital Market, East ASIA Capital Market, and Interest Rate

\begin{tabular}{|c|c|c|c|c|}
\hline $\begin{array}{c}\text { ASEAN } \\
\text { CM }\end{array}$ & $\begin{array}{c}F- \\
\text { Statistic }\end{array}$ & Prob. & $\begin{array}{c}\text { Adj. } \\
\text { R- } \\
\text { Squared }\end{array}$ & $\begin{array}{c}\text { Durbin- } \\
\text { Watson } \\
\text { Stat. }\end{array}$ \\
\hline $\begin{array}{l}\text { Transactions } \\
\text { Buy Foreign } \\
\text { Investors }\end{array}$ & 1.324 & 0.295 & 0.1218 & 2.2597 \\
\hline $\begin{array}{l}\text { Transactions } \\
\text { Sell Foreign } \\
\text { Investors }\end{array}$ & 0.9279 & 0.5438 & -0.0319 & 2.732337 \\
\hline $\begin{array}{l}\text { Transactions } \\
\text { Buy } \\
\text { Domestic } \\
\text { Investors } \\
\end{array}$ & 0.6458 & 0.6458 & $\begin{array}{c}- \\
0.096743\end{array}$ & 2.41563 \\
\hline $\begin{array}{l}\text { Transactions } \\
\text { Sell } \\
\text { Domestic } \\
\text { Investors } \\
\end{array}$ & 1.97516 & 0.10674 & 0.30236 & 2.087491 \\
\hline
\end{tabular}


Figure 1.

Buy and Sell Transactions of Domestic Investor Shares and Foreign Investors
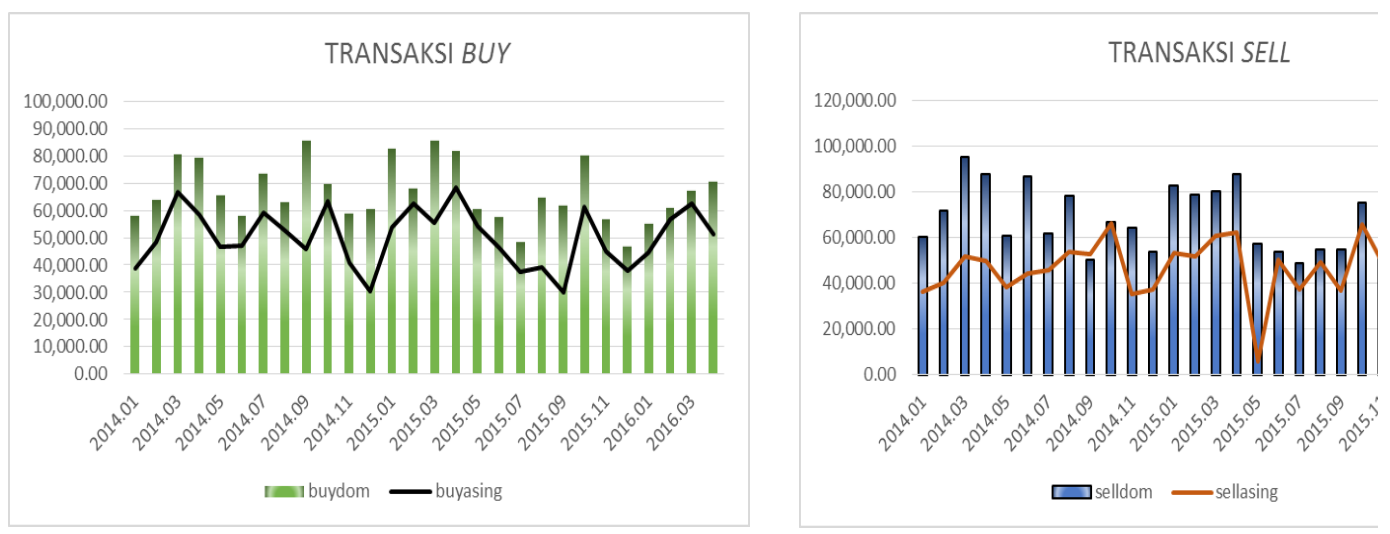

Source: IDX data processed (2016)

Figure 2.

Graph of Changes in ASEAN Capital Market

Figure 2. Graph of Changes in ASEAN Capital Market

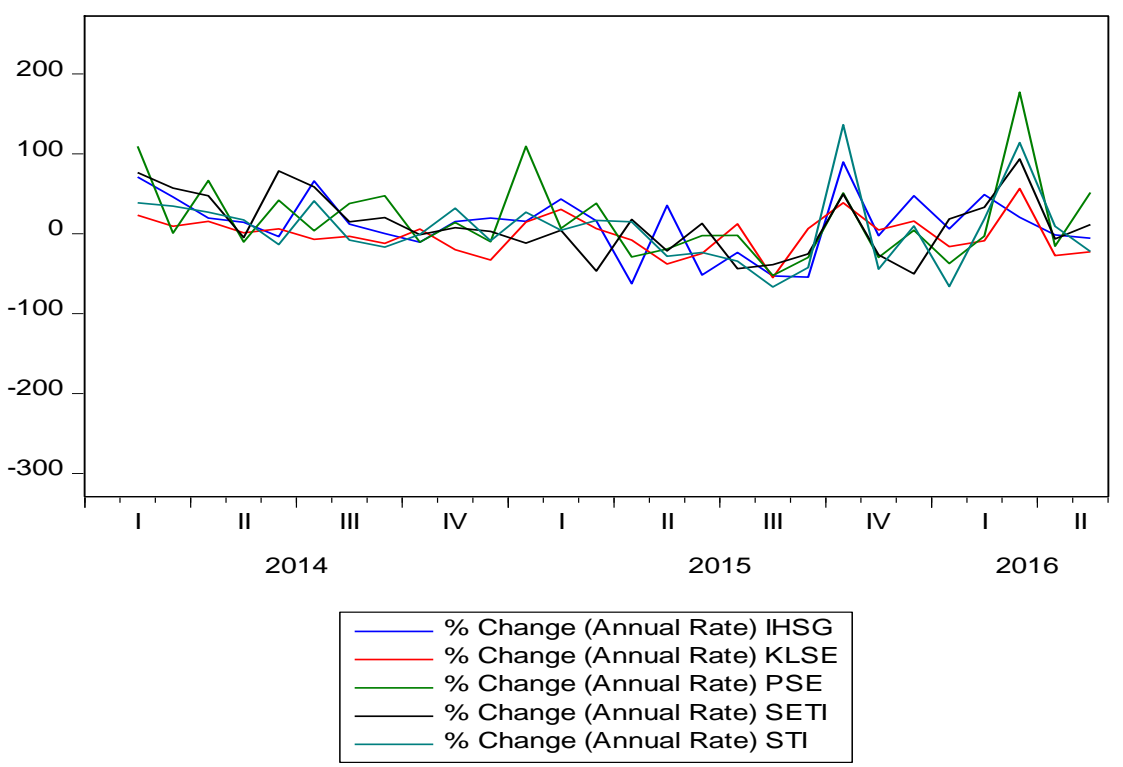

Source: Processed Data EViews 9 
Figure 3.

Thinking Framework

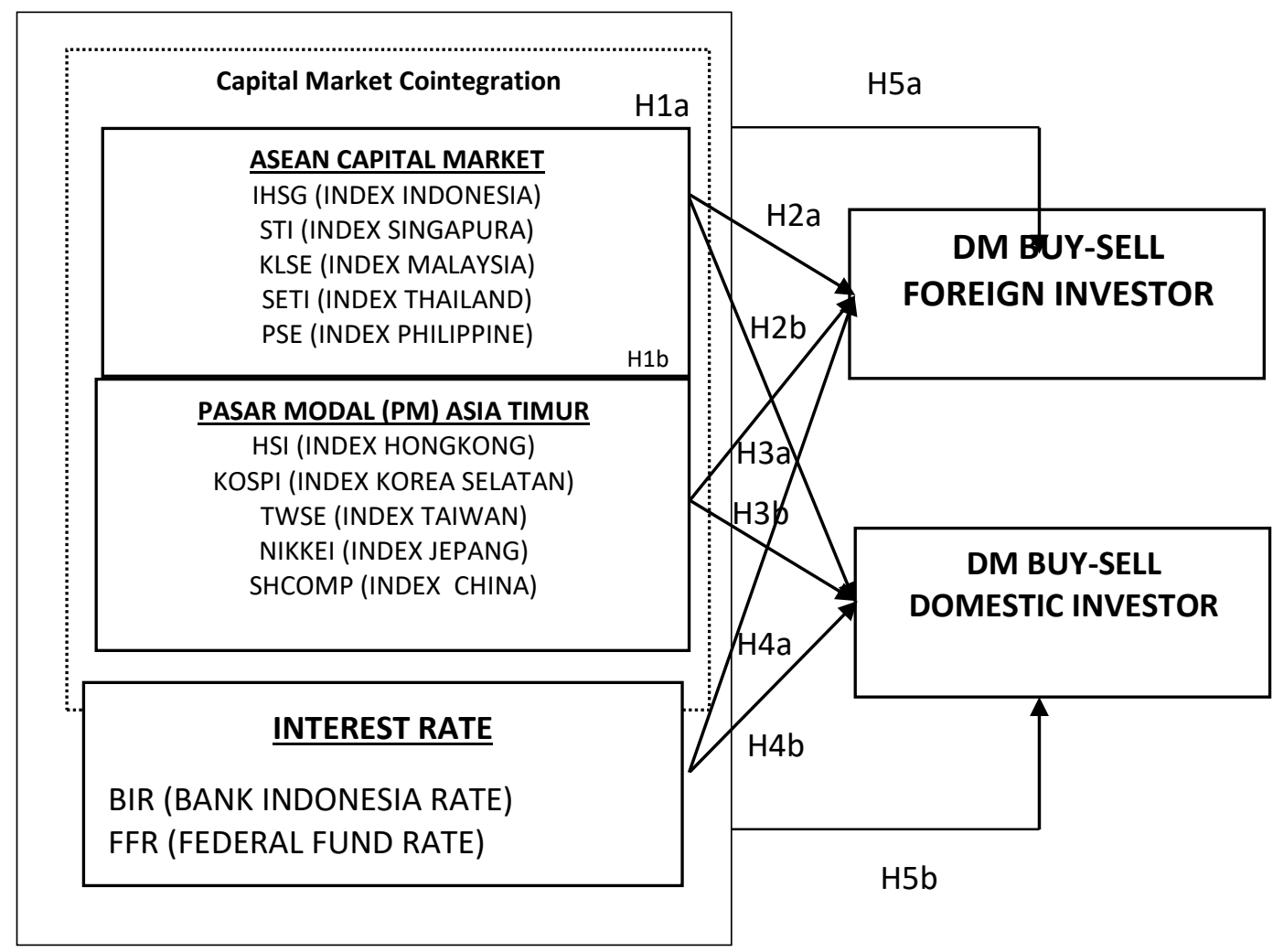

